\title{
Politologia
}

\section{Judicial activism and the American election process ${ }^{1}$}

\section{Paweł Laidler}

Jagiellonian University in Kraków

\section{Abstract}

This article analyses the phenomenon of judicial activism in the American electoral process. It tries to estimate whether the political system of the United States of America has become hostage to the law-making role of the judiciary, which actively controls the compliance of election laws with the Constitution, thus drawing courts into purely political processes, or whether the nature of the disputes settled by judges rather makes it impossible for them to avoid being influenced by and influencing issues of a political nature. The article analyses various legal acts and court decisions, mostly concerning the current status of federal campaign finance in the United States, and demonstrates that more spheres traditionally reserved for other branches of government are being appropriated by the judicial branch.

\section{Key words}

judicial activism, electoral process, U.S. Supreme Court, campaign finance

\section{Introduction}

Clections constitute one of the most important elements for measCuring how the rule of law and democracy function in a particular legal and political system, especially when the system was established in an era when the factors determining the democratic state of law were much less complex than nowadays. In analysing the process by which American statehood was forged - based on the first written constitution

1 Part of the research underlying this article was conducted in 2014-2016 and resulted in the publication (jointly with Maciej Turek) of the book Cena demokracji. Finansowanie federalnych kampanii wyborczych w Stanach Zjednoczonych Ameryki (2016). 
in the world - any efforts aimed at finding a direct reference to the rule of democracy or the state of law will be futile, since for the authors of the Constitution the superior idea around which the political system was built was the republic (The Federalist No 10). However, together with the idea of the nation's independence, expressed in the first words of the American Constitution ('We the People..., the Preamble), as well as the provisions establishing an independent federal judiciary (Article III) and the guarantee of a republican form of government (Article IV), the issue of elections was a key tool in implementing the idea of a democratic state and the rule of law into the constitutional order of the United States of America.

A characteristic feature of the American system has become that the courts can exercise a greater influence on social and economic issues, and sometimes on political issues as well, a feature which has been particularly visible in the past few decades (Laidler 2011). One can clearly observe the process of active judicial involvement in American politics, resulting in a more or less direct influence of judges on the public debate and political decision-making processes (Skrzypiński 2014; Laidler 2015). This concept particularly refers to the degree of the influence exerted by the judicial branch on political decisions which traditionally belong within the competencies of other branches of power (Shapiro, Sweet 2002). The omnipresence of courts in the political, economic, and - above all - social dimension of the United States, strengthened by the far-reaching activism of judges (Banaszak, Bernaczyk 2012), accounts for the fact that the judiciary is becoming one of the main determinants of the political development of the state. Although both the basic federal law and the long-standing constitutional practice indicate the law-making role of the legislative branch (the US Congress), one can observe and ever more frequent discussions in the scientific discourse on the influence of judicial decisions on the way in which the American state and the society functions, along with criticism of the scope of this influence (Wieciech 2014; Whittington 2007; Tushnet 1999). A clear example of the above-mentioned trends is the issue of elections as broadly understood, thus this article analyses 
the phenomenon of active judicial involvement in the American election system and tries to find the underlying reasons for this phenomenon, as well as analyses its effects. It is particularly worth asking whether the constitutional system of the United States of America has become hostage to the law-making role of the judiciary, which actively controls the compliance of the law with the Constitution, thus involving courts in purely political processes; or whether the nature of the disputes settled by judges makes it impossible for them to avoid influencing issues of a political nature.

\section{The federalization of the election process}

In accordance with the provisions of Article I of the Constitution, all issues related to the course of the election processes were to be regulated above all by the states, though the Congress retained the right to decide on the time and place of holding federal elections (Article I, section 4, clause 1). Granting states the priority in establishing the rules for conducting elections to the federal legislative branch was mainly attributed to the fears of the delegates concerning giving the central government a monopoly in making decisions relating to the manner of electing the members of Congress (Collier, Collier 2007). In spite of the assurances made by the authors of the Constitution that the House of Representatives and the Senate would regulate election issues only in extraordinary circumstances, the frequency of federal interventions in the election process has been significant enough (Peacock 2005:72) that one may talk about a progressing process of federalization of the election law. An example of some of the most significant interventions would include, on one hand, various legislative initiatives of the Congress, on the basis of which a series of amendments to the Constitution were introduced as well as acts regulating the election process, and on the other - the growing dominance of the central government in creating regulations concerning the financing of election campaigns to federal posts.

While theoretically the states remain responsible for the organization and the course of federal elections in their respective states, the constitutional 
practice demonstrates the ever-increasing role of the US Congress in regulating election procedures. Congress, the federal law-maker, has frequently taken the legislative initiative to regulate, via congressional acts, such issues as the introduction of a single date for the elections to the House of Representatives (17 Stat. 28,1872 ) and the Senate (38 Stat. $384,1914)$, to limit racial discrimination in election processes (79 Stat. 437,1965 ), or to regulate the rules of voting in federal elections (107 Stat. 77, 1993; 116 Stat. 1666, 2002). The Congress was also responsible for initiating fundamental modifications in the election system via amendments, i.e. referring to the procedure of electing the president $\left(12^{\text {th }}\right.$ and $22^{\text {nd }}$ amendments), or widening the voting rights to include African Americans ( $15^{\text {th }}$ amendment), women (20 ${ }^{\text {th }}$ amendment) and people aged over eighteen ( $26^{\text {th }}$ amendment). While these were based on the coresponsibility of both Congress and the states in passing amendments, in fact they were first passed by Congress and then accepted by $3 / 4$ of the states in the ratification process (Article V), making it difficult to assume that these issues were not related to the influence of Congress. However, the largest number of the Congressional interferences in the election system have by no means been constitutional amendments, but rather statutory provisions, which often have concerned the issue of financing federal election campaigns.

Since the second half of the $19^{\text {th }}$ century at least a dozen federal acts have been passed regulating various issues related to the flow of funds in election campaigns to the Congress and to the office of President. The main reason behind the central government's active participation in regulating the course of federal election campaigns has been the growing role of money in the process of campaigning for high federal positions in the country, which was a the derivative of the system of patronage and the spoils system (James 2006: 39-60). In order to counteract such practices, Congress passed the Pendleton Act in 1883, which established a new category of federal officers, who were appointed to the post via an objective competition process rather thanks to their ties with specific political parties (22 Stat. 43). This legislation, however, did not solve the problem of big money in election campaigns - it just changed 
the source from which donations came, diminishing the role of political parties and replacing them with corporations. Thus in 1907 Congress passed the Tillman Act, aimed at stopping the unlimited inflow of funds from corporations in elections, thus becoming the first regulation in US history creating the requirement that candidates reveal information on their contributions and expenses in election campaigns to the highest positions in the country. The Act also forbade corporations to make any donations in election campaigns (34 Stat. 864).

In the following years the Congress decided to introduce the first limitations on expenditures in election campaigns for federal offices, culminating in the Federal Corrupt Practices Act of 1910, which regulated the flow of money in campaigns for seats in the House of Representatives and required candidates to present accounts of their expenses (36 Stat. 822, 1910), as well as a later amendment to the Act which extended expense limits in campaigns to the Senate and in primary elections to both Houses of Congress (37 Stat. 25, 1911). This was the most important legislation in the first half of the $20^{\text {th }}$ century, upholding limitations on the amount of funds spent in campaigns, forbidding corporations to finance candidates, and tightening procedures concerning the filing of financial accounts of election campaigns by increasing their frequency by four times ( 43 Stat. 1070). The regulations introduced by the Federal Corrupt Practices Act remained valid until the 1970s, when Congress began to interfere into the financing of federal election campaigns on an unprecedented scale.

This next reform of the election system, which was saturated with millions of dollars of donations from private sources and tainted by numerous corruption scandals, was initiated in 1971 with the passage of the Federal Election Campaign Act, which introduced separate limits on expenditures for both Houses of the Congress and in presidential elections, limiting expenses on media campaigns, and improving the transparency of financial accounts (85 Stat. 497). As a result of the Watergate scandal, the greatest achievement of which was the establishment of the Federal Election Commission - an administrative agency equipped with competences allowing it to supervise the course 
of federal election campaigns, and especially their financing. At the same time limits were set on candidates' expenses within a given election cycle and - what is of vital importance - the Act included limits on donors who financially support candidates for federal offices, as well as initiating the implementation of a system of public financing of presidential elections (88 Stat. 1263, 1974). Further amendments to the Federal Election Campaigns Act resulted from the Supreme Court's rulings on the Act, which led firstly to abolishing the limits on expenses incurred during the election campaigns, leaving only limits concerning those candidates who decided to partly use financing from public means; secondly to changes in the system of electing members of the Federal Election Commission (9o Stat. 475, 1976); three years later, to the introduction of changes to the system of reporting expenses incurred during a campaign; and finally to granting political parties the right to unlimited expenditures during election campaigns (93 Stat. 1339, 1990).

The last significant US Congressional legislation regulating the process of financing elections was the Bipartisan Campaign Reform Act of 2002, which was the result of certain abuses in the presidential elections in the 1990 s and the growing influence of so-called 'soft money', raised in an unlimited way by political parties (Oświecimski 2011: 260-266; Turek 2013: 176-185). This Act forbade parties, party political committees, and related organizations to raise and spend funds in elections on the federal level which would not be subject to federal jurisdiction and to oversight by the supervisory institutions operating by the virtue of such jurisdiction. Also, the significance of issue advocacy, which consists of preparing issue announcements during an election campaign which do not refer directly to a candidate, was limited and the Act introduced a new category of election communications used in issue advocacy, passed on both via the media and in primary elections (116 Stat. 81).

The numerous above-cited examples demonstrate the increasing process of federalization of issues related to the course of the federal election process. Leaving aside the evaluation of the merits of the initiated 
reforms, which were aimed at limiting the flow of big money in election campaigns and/or at standardizing certain elements of the election process, it must be said that at present it is the federal government which seems to be the chief playmaker in US election law. Although the above-mentioned reforms mostly refer to issues related to federal elections, it is worth emphasizing that both the vision of the authors of the Constitution as well as its content unambiguously indicated that states were to be the main subjects regulating election issues. However, leaving aside the issues related to appropriation by the US Congress, it turns out that their appropriation of this domain does not constitute the greatest challenge facing contemporary American constitutionalism. The greatest challenge is the active judicial involvement in this process.

\section{The rulings of the courts on election issues}

One specificity of the regulations introduced by the Congress over the years consists of the fact that the federal legislation on election issues is subject to many checks vis-à-vis the compliance of the adopted solutions with the Constitution. American courts, led by the Supreme Court, have taken an active part in the process of redefining the concepts related to the election process, especially the principle of equality of elections, the establishment of electoral districts, banning discrimination or the flow of election funds, and verifying whether the regulations passed by the Congress are compliant with the Constitution. It has turned out that a significant number of court rulings have not only invalidated existing regulations, but also introduced a new perception of the procedures related to elections, thus determining the nature of the contemporary American election system. Without deprecating the judiciary's fundamental competence to control the compliance of the law with the Constitution, which is a fundamental principle in the American system, one should consider whether the issues in the subsequently analysed court rulings are purely political, which in theory would be preventing the judicial branch from interfering in this sphere of the country's operations. 


\section{Elections - a political question?}

The above query is justified not only in the views of the authors of the Constitution, as the majority of them saw the role of the judicial branch limited to settling disputes resulting from violations of the law (The Federalist No 78), but also in some of the rulings of the Court itself, which has marked the limits of its control of the compliance of the law with the Constitution. In 1962, in the Baker v. Carr dispute, the justices claimed that they had the ability to resolve conflicts related to the procedure of delineating the boundaries of the election districts by state legislatures. The court ruled that any attempt at redistricting which would infringe on the principle of equal representation should be deemed to be a violation of the clause guaranteeing the equal protection of the laws, contained in the $14^{\text {th }}$ amendment to the Constitution (369 U.S. 186). Paradoxically, in the same ruling the justices elaborated on the 'political question' doctrine. This doctrine refers to those matters which, due to their purely political nature, should not be adjudicated by the judicial branch. However, in the opinion of the majority of justices, in spite of the political dimension of the election process the issue of establishing the borders of election districts by the states could not be excluded from the jurisdiction of the judicial branch (ibid.).

An immediate effect of the Baker v. Carr decision, handed down in 1962, was the filing of a large number of disputes concerning the redistricting process, to which as many as thirty-six states were parties (Hall, Ely 2009: 23). One of the most significant disputes concerning this issue was Gray v. Sanders, in which the Supreme Court found the system of establishing the boundaries of legislative districts in state elections which preferred the less-populated areas to be unconstitutional, and the words of Justice William O. Douglas, promoting the 'one man one vote' principle earned him a place in history (372 U.S. 368, 1963). A few months later, in the Wesberry v. Sanders dispute, the Court once again ruled that electoral districts which differed significantly in terms of the size of the populations they represented violated the principle of equality under the law (376 U.S. 1). What is remarkable is that the Supreme Court justices clearly emphasised that issues concerning 
the election law did not constitute a 'political question', and therefore could be settled by the judicial branch.

In 1964 the Court issued decisions in six disputes, settled collectively under the name Reapportionment Cases, concerning the method of redistricting used by state legislative bodies ${ }^{2}$. The leading dispute, in which the fundamental ruling for the American election system was issued, was in the case of Reynolds $v$. Sims, which concerned controversial regulations of the process of elections passed by the legislative body of Alabama. On the basis of the existing provisions and the existing state practice, the inequalities between particular districts were so huge that from the theoretical point of view candidates to both houses of the state legislative body could be elected by a quarter of all state citizens with election rights. The differences between the representations in particular districts were 16 to 1 in the election to the lower chamber, and as high as 41 to 1 in the election to the upper chamber (Hall, Ely 2009, 296). By declaring the existing state regulations unconstitutional, the Court confirmed the constitutional nature of the one man - one vote principle as a fundamental guarantee resulting from the necessity to enforce the principle of equality under the law. The judges compared the irregularities in the redistricting processes existing in many states to a conscious act performed by the state legislative bodies, which consisted of giving a greater number of votes to one section of the society to the detriment of other sections, emphasising that that the size of the population is the only factor that determines the process of establishing the borders of districts (377 U.S. 633). In spite of many difficulties encountered in the direct enforcement of the Court decision in all states, the Reynolds ruling has become a milestone in implementing the principle of equal political representation in elections in the United States, confirming

2 It comprised the following disputes: Reynolds v. Sims 377 U.S. 633 (1964), WMCA v. Lomenzo 377 U.S. 633, Maryland Committee for Fair Representation v. Taws 377 U.S. 656 (1964), Davis v. Mann 377 U.S. 656 (1964), Roman v. Sincock 377 U.S. 695 (1964) and Lucas v. Forty-Fourth General Assembly of Colorado 377 U.S. 713 (1964). 
the possibility of review by the judicial branch of those actions of state powers which had attributes of discrimination.

\section{Gerrymandering}

In American constitutionalism, the intentional manipulation of the shape of a legislative district by the state authorities so as to prefer one group of supporters or a particular political party, or to discriminate against supporters of another particular political party is called 'gerrymandering' (Greenberg, Page 2005: 327). In the political practice of the United States we can distinguish many methods of implementing gerrymandering by state authorities, though the two most common methods are the 'packing method' (determining the borders of a district so to cover the largest number of supporters of a particular party); and the 'cracking method' (dividing an area in which a particular party has strength into parts of other districts in order to disperse its voters) (Sokół 2013: 52; Kozłowski 2014: 287).

The Supreme Court has voiced its opinion on the constitutional nature of political gerrymandering several times, and one of the most important decisions in this matter was issued in 1986 when the Court criticized this practice in the Davis $v$. Bandemer case. The judges ruled that political gerrymandering may be considered unconstitutional if, after drawing the new boundaries of a given district, some voters are promoted or discriminated against, thus violating the principle of a fair election process (478 U.S. 109, 1986). However, the fact that representatives of a certain group of voters were not elected is not in and of itself sufficient, according to the Court, to declare that the legislative districts were formed in an unlawful way. The issue of political gerrymandering aroused the Court's interest once again at the beginning of the $21^{\text {st }}$ century, when judges decided to settle the Vieth v. Jubelirer dispute concerning the constitutionality of redistricting in Pennsylvania, which turned out to be beneficial to the candidates of the Republican Party. The majority of judges not only decided to rule that the changes in the borders of districts was compliant with the law, but they also advocated excluding the issue of political gerrymandering 
from the court's jurisdiction, arguing that the process of establishing electoral districts has always been marked by political factors and that the Constitution itself does not exclude taking these factors into account when determining the boundaries of districts by the state authorities (541 U.S. 267, 2004).

While politically-motivated gerrymandering, which has given rise to controversies since the beginning of the $19^{\text {th }}$ century, has ceased to be an interesting issue for the courts, redistricting in order to discriminate against racial minorities (racial gerrymandering) has remained one of the biggest contemporary challenges related to the process of determining legislative districts' borders. This issue was first clearly defined by the federal judicial authorities in the 1980s, that is during the times when the constitutional legitimacy of affirmative action programs was being debated (Ball 200o). In 1986 the Supreme Court issued its ruling in the Thornburg $v$. Gingles case, which led to forbidding any form of racial discrimination when determining changes in the borders of districts (redistricting), even if such discrimination was unintentional (478 U.S. 30). As a result, many districts were re-drawn so that African Americans (and in some cases Latin Americans) had the largest number of voters in a given area, thus increasing their chances of electing their own representatives. The Court objected to such actions by issuing decisions in two disputes in the 1990s, namely Shaw v. Reno and Miller v. Johnson, in which white Americans challenged the redistricting processes in North Carolina and Georgia, respectively. The former case was particularly interesting, as a federal authority was involved in the process of determining districts' borders in North Carolina in order to promote the policy of equal opportunities for African Americans in public life. Relying on the clause of equal rights under the law, the judges forbade gerrymandering based on racial factors (509 U.S. 630, 1993), which was subsequently confirmed in the Court ruling in the Miller case (515 U.S. 900, 1995). To summarize, the interference of American courts in the processes of establishing and modifying legislative districts took place more often when judges discerned the possibility of discrimination 
against particular social groups by the state authorities responsible for those processes.

\section{Financing election campaigns}

Although the Supreme Court examined the constitutionality of federal legislation concerning the financing of election campaigns as early as in 1921 in Newberry v. United States (256 U.S. 232), this type of judicial review intensified only in the 1970s, following a serious reform of the election financing system implemented by Congress. The fundamental ruling of the Court which changed the nature of financial participation in election campaigns was issued in 1976 in Buckley v. Valeo. In analysing the provisions of the Federal Election Campaigns Act of 1974 and its amendments, the Court found part of the law unconstitutional and, inter alia, abolished limitations on campaign expenditures and questioned the way in which members of the Federal Election Commission were elected. In the majority opinion, judges focused on protecting donors and candidates participating in election processes, whose expenses were considered a form of a political statement, protected by the constitutional guarantee of freedom of speech. The judges considered the limits placed on expenses made by candidates themselves and their election committees, as well as other entities, as unconstitutional if such donations were made in connection with the campaign, but not directly for the candidates. The Court also found unconstitutional the provision which imposed limits on the expenses of candidates who decided to finance their election campaigns with their own funds (424 U.S. 1).

In this way, for the first time in history judges ruled on campaign financing laws using the prism of the First amendment to the Constitution which guarantees, among other basic freedoms, freedom of speech. This approach was to shape the future debate on the importance of money in elections. In the content of the ruling several references are made to the 'supreme interest of the state' as the only possible foundation for excluding the constitutional protections guaranteed for all participants in political processes. The Court found such a 'supreme state interest' to be present in laws limiting the size of individual contributions for 
candidates in elections, emphasizing that such limits help prevent corruption. A similar goal was behind the transparent and effective system of accounting (reporting), thanks to which citizens could learn about the sources of payments and the entities making them. However, in the opinion of the Court the striking down of statutory limitations on election expenses would not negatively affect social trust in the election system. On the contrary, it helped to secure freedom of speech, which is one of the superior values of democracy (ibid.).

Thus, until the 1970s the issue of financing federal election campaigns seemed to be an exclusive domain of Congressional legislation, especially due to the political nature of the pertinent regulations. However, since 1976 American courts, and especially the Supreme Court, have become an arena in which a debate is ongoing over controlling the flow of money in federal election campaigns on one hand, and the protection of constitutional rights of the subjects taking part in the process on the other.

In the last two decades of the $20^{\text {th }}$ century, the Supreme Court often presented its position in the discussion over the constitutionality of the federal legislation, mentioning a few vital issues related to the financing of election campaigns, and its rulings revealed a growing divide between the liberal and the conservative approach to the nature of such regulations. Thus, in the California Medical Association v. F.E.C. dispute concerning the violation of a limitation on the amount of funds raised by the political action committee (PAC) of the California doctors' association for the election campaign to the Congress, the Court upheld the existing regulations, stating that the limitations imposed on contributions made by associations for particular candidates in elections do not limit the freedom of speech of the subjects financing candidates for the Congress, and they are in accord with the national interest in ensuring the integrity of the election system (453 U.S. 182, 1981). However, nearly four years later, in F.E.C. v. National Conservative Political Action Committee, the Court agreed with the argument that the constitutional protection of freedom of speech placed limits on the possibility of the federal government to interfere in the issue of election financing 
by political action committees (PACs). As emphasized in the majority judgment by chief justice William Rehnquist, these organizations constituted an important element of the election process, therefore their independence could not be limited by the state (470 U.S. 480, 1985).

Apart from the issue of political action committees, in the $198 \mathrm{os}$ the Supreme Court also rendered its judgment on various forms of political electioneering during election campaigns financed by various individuals. One case concerning this issue was F.E.C. v. Massachusetts Citizens for Life, which concerned the constitutionality of an information brochure published before the election by an organization promoting candidates who opposed abortion. The justices had no doubts that the $1^{\text {st }}$ amendment to the Constitution protected such statements, and they referred above all to issue advocacy, which consists of promoting vital socio-political issues, not specific candidates (479 U.S. 238, 1986).

In the 1990s the Court issued further rulings, but in none of them did it find key regulations of Congressional legislation to be unconstitutional. One of those rulings, in the Colorado Republican Federal Campaign Committee v. F.E.C. case, resulted in upholding the argument that campaign financing was an implementation of the principle of freedom of speech, and also confirmed the rights of parties to participate in the process of making contributions related to elections, provided that such donations were not given directly to the candidates but instead referred to the advocacy of a particular issue constituting the subject of public debate ( 518 U.S. 604, 1996). A ruling from 2001 seems equally important, as it demonstrated the growing dispute within the Court concerning the proper interpretation of the right to finance election campaigns. The F.E.C. v. Colorado Republican Federal Campaign Committee case concerned the issue of so-called 'coordinated expenses', that is donations for a candidate made in connection with them, contrary to contributions made independently of them. The Supreme Court, though seriously divided, upheld the validity of the norms limiting this type of expenses, since such norms did not negatively affect the activity of political parties and other organizations in the process of financing election campaigns (533 U.S. 431). 
After the last significant reform of the system of financing election campaigns, i.e. Bipartisan Campaign Reform Act of 2002, judges soon faced the challenge of determining the constitutionality of this legislation. In McConnell v. F.E.C, most justices upheld the key regulations adopted in the Act, emphasizing that the scale of limitations introduced by it is not significant and does not in any way violate the principle of freedom of speech of the entities participating in the election process. On the contrary, these provisions guarantee the superior interest of the state, consisting of limiting corruption and ensuring the transparency of election processes (540 U.S. 93, 2003). The justices argued that the law-makers were right to eliminate the possibility of the flow of soft money in election campaigns, since the past experience indicated that some organizations would often support both political parties, thus demonstrating that the true motive for their actions was not ideology but the desire to maintain political influence. Soft money, according to the justices, was the source of many manipulations, not only in election campaigns but also in the legislative process, thus increasing the probability of corruption, which was defined in McConnell very broadly (Mutch 2014: 171-172).

However, the changes in the composition of the Supreme Court in 2005 determined, due to the advantage gained by the conservatives on the Court, the future direction of the rulings given by the federal judicial branch in disputes over the right to finance federal elections, (Rosen 2007: 213-214). The first case in which the new coalition became visible was F.E.C. v. Wisconsin Right to Life, where an organization opposing, inter alia, any form of abortion or euthanasia, prepared election publications which recommended supporting senators who advocated for the protection of conceived life. The justices did not find any violations in the law, emphasizing that the act forbade the publication, during a specified time, of content aimed at promoting or discouraging citizens from voting for selected candidates for federal offices, which - in their opinion - was not the case in this situation. Once again the justices cited the argument positioning freedom of speech as the key value guaranteeing public discourse on important social 
and political issues during election campaigns (551 U.S. 449, 2007). Nearly a year later, in the Davis v. F.E.C. case, the Court, by a 5-4 vote of the five conservative justices, stated that the provisions of the Act making it possible to abolish some limitations to contributions for those candidates whose opponents in the election race have raised over 350,000 dollars are unconstitutional. The majority opinion, given by Associate Justice Samuel Alito, emphasized that the limitations on expenses, applicable to rich candidates, violated the $1^{\text {st }}$ amendment, especially because such limitations were abolished for their poorer opponents (554 U.S. 724, 2008).

Finally, in 2010 in Citizens United v. F.E.C., the Court issued a ruling which is considered to be one of the most controversial in its history (Kubas 2013: 437-439). The subject of the controversy was the provision of the Act stating that corporations could not issue election communications during a period of up to 30 days before primary elections and up to 60 days before the main elections. The facts of the case referred to the events during the period of primary elections to the presidential election of 2008 when, due to the statutory limitations, the emission of a movie financed by Citizens United, a conservative corporation, was halted. The film criticized Hillary Clinton as a candidate of the Democratic Party for the office of President. Although the dispute directly concerned the issue of election communications, the Supreme Court conducted a wider analysis of the provisions of the Act of 2002 in the context of the freedom of speech guarantee. The conservative majority in the Court, relying on the essence of the Buckley ruling, emphasized the significance of financial contributions for the proper course of election processes as an important type of political statement. Finding the limitations placed on corporations and other organizations in their publishing of electioneering communications to be unconstitutional, the justices emphasized the role of such organisations as contributing entities, giving them an equal position in election campaigns to that enjoyed by individual donors. They explained that when organizations associating members on a voluntary basis engage in political activities, representatives of these organizations should be treated as advocates for 
their members' interests. Therefore, in the Court's opinion corporations were not only allowed to issue election materials without any time limits, but also such materials could refer directly to the candidates taking part in election campaigns (558 U.S. 310).

Four years later, the Supreme Court handed down another important decision referring to the scope of the right to finance election campaigns. The McCutcheon v. F.E.C. dispute concerned the constitutionality of a limit placed on the total amount that could be spent by particular donors on election campaigns in a given election year. The Court shared McCutcheon's argument and abolished the limitations on the amount of expenditures on election campaigns during a two-year election cycle, arguing that it is necessary to protect freedom of speech and the right to choose the amount of contributions for candidates and political parties. The justices acknowledged that all limitations to election contributions must be justified by the state interest in fighting corruption among civil servants, and in the case of the limit on the sum of expenses in a particular election cycle no such interest could be discerned ( 572 U.S. 12-536). It should be noted that the Court upheld the limits on individual contributions for a candidate, though admittedly one of the justices, Clarence Thomas, put forward the argument that all limitations concerning the amount of contributions in election campaigns should be abolished. As he stated, limiting the amount of contribution that a person may give to a candidate directly limits such person's political message (ibid.). We may wonder whether this position implies the dawning of a new era in abolishing statutory limitations on political participation in terms of the financing of elections and thus augurs a far-reaching judicial activism in election processes.

\section{Shelby County v. Holder}

Another example of the major influence of the Supreme Court on the election process is a ruling from 2013, Shelby County v. Holder. Before we present it, it should be noted that the above-mentioned federalization of the election process was aimed at annulling those state regulations which were of a discriminatory nature. Due to legislation discriminating 
against African Americans and other racial and ethnic minorities passed in many southern states in the second half of the $19^{\text {th }}$ century and the first half of the $2 \mathrm{O}^{\text {th }}$ century, when implementing its racial desegregation policy, Congress enhanced the formal control that federal institutions had over the ways in which the state election laws were amended, especially in those states where discrimination was historically the most serious. As a result, when implementing the Voting Rights Act in 1965 an Act emblematic of eliminating racial discrimination in the political process - it was decided to introduce some supervisory mechanisms limiting the freedom of the states to regulate their elections. This Voting Rights Act, labelled 'the greatest success of civil rights legislation in history' (Wilson 2015: 182), created a list of states and local governments which, due to their history of discrimination policies, could be subjected to special supervision and restrictions by the federal government. These restrictions were defined explicitly in the Act and could be established in the future on the basis of new legislation or amendments to the Act (section 4 b). In this way, the so-called 'coverage formula' was created, determining which states or local governments introduced limitations on access to the process of election registration or the act of voting, usually by implementing such tools as literacy tests, requirements concerning the degree of education, documented certificates of good conduct, or a special certificate authorizing its holder to vote, etc. (ibid.). In addition to establishing a list of those state jurisdictions historically responsible for discrimination policies, the Act of 1965 was extended to cover more states in amendments to it passed in 1968 and 1972, as a result of which during some periods of time federal supervision and control covered nearly half of all American states ${ }^{3}$.

The above-mentioned control was manifested in the requirement that particular states or local authorities needed to obtain permission to make any changes concerning the regulation of the election process,

3 In all, 21 states were fully or partly covered by the control of the act: Alabama, Alaska, Arizona, California, Connecticut, Florida, Georgia, Hawaii, Idaho, Louisiana, Maine, Massachusetts, Michigan, Mississippi, New Hampshire, New York, North Carolina, South Carolina, South Dakota, Texas, Virginia. 
such as amendments to the principles of election registration, methods of voting, or the act of voting itself. The states had to prove that all modifications falling within the scope of control were not aimed at or would not lead to any form of discrimination (section 5). From the institutional perspective, the supervisory competencies were passed on to the United States Attorney General or the District Court for the District of Columbia, and the choice between administrative and court proceedings was vested in the state or local authority which introduced changes to the election law (Sellers 2015, 369). Apart from the standard procedure, one of the amendments to the Act allowed special federal inspectors, acting on the order of attorney general, to exercise federal control over the implementation of new state regulations. It is important to note that these officials not only performed supervisory functions, but were also authorized to make administrative decisions consisting of, inter alia, registering voters who were passed over as a result of discriminating procedures implemented by state or local authorities (Wilson 2015: 185-186).

In 2006 Congress voted that section 5 shall remain valid in connection with section $4 \mathrm{~b}$ of the Act, adding some minor amendments (ibid.), which aroused protests on the part of those states deemed to have a history of racial segregation in election processes. In their opinion, the validity of sections $4 \mathrm{~b}$ and 5 of the Act was not compliant with Article IV and the $10^{\text {th }}$ amendment of the Constitution, which guaranteed the states on one hand full control over the process of establishing election regulations, and on the other ensured the equality of all states. The Shelby County v. Holder dispute was finally settled in 2013, when the Supreme Court found section $4 \mathrm{~b}$ to be unconstitutional, especially with reference to the 'coverage formula', which in the Court's opinion led to the unequal treatment of states by the federal authority when carrying out its competences resulting from the election law. According to the five conservative justices who signed the majority opinion, the Act, based on findings from several decades ago, should not be used and it was necessary to annul the provisions concerning federal control over 
the states related to the alleged discriminating election regulations (570 U.S. 2).

Many commentators believed that the Court's decision would directly affect election participation in forthcoming election cycles. It was assumed that the states whose limitations had been abolished would be free to implement reforms of their election system aimed at obtaining a particular election result. The liberals and the conservatives had totally opposing views on this matter: the former criticized the ruling, seeing it as a threat to the principle of equality of the election process; while the latter considered it a guarantee of the states' constitutional right to determine the principles governing their elections (Darby 2016: 329346). It is true that as a result of the Shelby County ruling many state authorities decided to introduce additional requirements that had to be met in order to take part in the voting procedure such as, for example, the necessity to present an identification document with a photo or two different identification documents to the election committee (which constituted an extension to the existing regulations in this area), or shortening the process of so-called early voting and early registration (Vandewalker, Bentele 2015). It is characteristic that a significant part of these state reforms of election laws were implemented by the decisions of Republican politicians, who - according to their critics - wanted in this way to make it more difficult for representatives of racial and ethnic minorities to vote. Though there is no conclusive evidence that the amended election laws in particular states affected the course and the result of the presidential election in 2016, it should be emphasized that the decision made by the Supreme Court allowed many southern states to verify their own procedures, which would have been impossible before the final decision in the Shelby County case.

\section{The causes and effects of judicial activism in the election process}

Since the 1960 s we can observe an increased activism on the part of the federal judicial branch in the sphere of adjudicating on the con- 
stitutionality of regulations related to election issues, as broadly understood. Although the activism of the Supreme Court is a common element of the election system in the United States at present, the areas in which the Supreme Court has interfered seem quite problematic from the perspective of the political question doctrine. As shown above, the theoretical foundations of this doctrine were established in the Baker v. Carr precedent, which, nomen omen, referred to the issue of dividing districts and assumed that judges should not settle disputes which, due to their clear political nature, belonged to competencies of other branches of power $(369$ U.S. 186, 1962). This approach harmonized with the doctrine of judicial self-restraint, created in the 1930s by judge Louis Brandeis in the so-called Ashwander rules (Ashwander v. Tennessee Valley Authority, 297 U.S. 288, 1936).

From the theoretical point of view it may seem curious that contemporary American courts play such a vital role in disputes concerning elections, especially in matters related to the financing of election campaigns, since this issue is closely related to the political aspects in which the legislative and executive powers operate. However, the above-cited opinions of the judges, and especially the justices of the Supreme Court, settling the 1960s' disputes over redistricting in order to guarantee equal representation, prove that even at that time the Supreme Court reinforced the jurisdiction of the federal judicial branch to determine the nature of the election process. The early rulings justifying the rights of courts to assess the constitutionality of actions performed by those state authorities responsible for redistricting, such as Baker v. Carr, Gray v. Sanders and particularly Wesberry v. Sanders, seem of vital importance. It was in the course of ruling on this latter dispute that the Court emphasized that issues related to election laws are not subordinated to the political question doctrine (376 U.S. 1, 1964). Moreover, in 1974 the Court issued its ruling in the United States $v$. Nixon case, in which it confirmed the power of the judicial branch to interpret the competencies of other branches of government if the analysed issue(s) concerned their legal nature (418 U.S. 683, 1974). All of these developments accounted for the fact that when ruling 
on the Buckley v. Valeo dispute, the justices did not have any doubts as to their jurisdiction over the issues of financing federal election campaigns, especially as that and subsequent disputes were connected with examining the constitutionality of the regulations introduced by the Congress and defining the scope of freedom of speech. This did not prevent the Court from considering some election issues raised in 2004 as being beyond the jurisdiction of the federal judicial power. For example when ruling on the Vieth $v$. Jubelirer case, the Court discerned political factors as lying at the foundation of political gerrymandering (541 U.S. 267). At present, especially in the context of the rulings in the Citizens United and McCutcheon cases, there would seem to be no grounds for assuming that a similar decision would be taken in the disputes concerning the constitutionality of the regulations governing the financing of election campaigns.

One of the problems of institutional relations between the legislative and the judicial branches concerning the financing of federal election campaigns is the activism the judges demonstrate when analysing the controversies over the flow of funds in election campaigns. Whereas the Buckley rule did not raise any doubts in the 1970s, at the end of the $2 \mathrm{O}^{\text {th }}$ century - when one of the effects of its implementation became visible, namely the significant influence of soft money on the course of election campaigns for the Congress and for the office of President - the argument that spending money on election purposes may be a constitutionally protected form of speech began to be challenged. However, the consecutive precedents of the Supreme Court and the directions in which congressional regulations have developed demonstrate the dominant and unquestionable significance of the 'money as a form of expression' rule. It gained a special dimension after implementing the last two key decisions of the Court in the Citizens United and McCutcheon cases. The reactions of politicians and analysts leave no illusions - if before 2010 there were some doubts as to which branch of power had final responsibility for the shape and nature of the laws governing the financing of election campaigns, the ruling in the Citizens United case clarified this situation. The discussion now 
features new arguments - that the Court has become political and that it has taken on the role of law-maker, a function constitutionally vested in the legislative power.

The interference of the federal judicial branch in the political dimension of actions carried out by particular branches of power is nothing new to observers of the American political scene. Since the beginning of American statehood there has been a process of expanding the powers of the Supreme Court as a constitutional court, and in the $20^{\text {th }}$ century the frequency of striking down federal legislation, partially or in full, increased significantly, which was the result of the dominance of judicial activism over the doctrine of self-restraint (Laidler 2011). This was particularly visible in the process of incorporating the Bill of Rights into the $14^{\text {th }}$ amendment and expanding the significance of some civil rights and freedoms, including those not directly written in the Constitution, and also in the choice to protect national security at the cost of civil freedoms in times defined as 'emergency' (Vile 2006).

Therefore, it cannot be said that the controversies related to the excessive interference of the Supreme Court in issues related to financing election campaigns has only appeared in contemporary times as a reaction to the Citizens United or McCutcheon precedents. Both decisions were the result of the long process of federalization of the election process which took place in the $20^{\text {th }}$ century, especially in the 1970s, when the Congress initiated far-reaching reforms of the election system. They are also a result of the rule, evolving since that time, which guarantees constitutional protection to entities making contributions for election purposes, though due to the effects that such precedents have on the future financing of election campaigns we should not be surprised by the intensity of the discussions concerning the political role of the judicial branch and the growing activism among judges. A good example here is the course of the Senate hearings held on the nomination of Elena Kagan for the Supreme Court. In 2010 she was appointed by President Barack Obama to replace John Paul Stevens, who rendered a great service in fighting the conservative coalition. It turned out that one of the leading topics of the hearings in 
the Senate Judiciary Committee was the ruling in the Citizens United case, which Kagan criticized, mainly due to the activism of judges in abolishing federal limitations concerning corporate participation in the process of financing election campaigns (Karlan 2013: 35). It should be emphasized though that the issue of judicial activism has appeared many times in the history of the Senate hearings held on nominees to the Supreme Court, and even more often in connection with the rulings of liberal justices than their conservative counterparts, which was well demonstrated in the Senate hearings of Robert Bork in 1986 (Vieira, Gross 1998: 27-29). The main conclusion to be drawn then is that political activity by the federal judicial branch is now a fact and constitutes an indispensable element of the contemporary American political system. Due to the key importance of the process of financing election campaigns for this system, it comes as no surprise that there are controversies concerning rulings by the Supreme Court which define the role of funds and the entities spending them, especially inasmuch as some analysts claim that judges settle the disputes concerning election issues taking into account their own opinions and beliefs rather than neutral principles of law (Hasen 2012: 1).

Analysis of all the significant rulings of the Supreme Court in matters concerning election processes demonstrates the existence of a thin line, determined by the justices themselves, which marks the allowable interference of the judicial branch into the course of elections. While it seems logical and necessary for the court to react to discriminatory actions aimed against specific social groups, redefining the significance of legislation having reference to strictly political issues seems less obvious. The judges themselves have noted this difference, distinguishing between two types of disputes over the designing of borders of legislative districts by state authorities - political gerrymandering and racial gerrymandering, the former falling outside judicial review and the latter being subject to it. It is a fact though that some political factors lie at the source of every discriminatory action, and since the politicians' goal is to secure the sufficient support of voters during an election it is easy to imagine a situation whereby redistricting is determined not only by 
geographical and population factors but also purely political calculations. Since the goal of every election is to win a particular political office, practically every dispute concerning a possible violation of the election laws or a differing interpretation of existing provisions will have political consequences, and thus may be considered to be of a political nature. Does this mean then that courts should not interfere in the election processes at all?

Attempts to limit judicial activism should not mean going from one extreme to another, since self-restraint does not mean a total lack of activity but only limiting it to absolutely necessary situations. One such absolutely necessary situation would seem to be the need to prevent the government from violating the rights and freedoms of individuals, including election rights such as the equality, freedom, or universality of the election process. Who - if not the judicial branch - can play the role of mediator in disputes resulting from alleged violations of the law? If we deprived American courts of the possibility to control the constitutionality of actions carried out by the legislative and the executive powers, would this bring about any benefits to the principles of democracy and the rule of the law? Over two hundred years ago the authors of the American Constitution assumed the necessity to guarantee the separation of powers and institute a system of checks and balances, in which the courts were to settle disputes between other branches of government. Currently, the omnipresence of the judicial power in political processes may cause us to question the real separation of powers and the effectiveness of mutual checks and balances. Undoubtedly courts have evolved much more than other branches, moving from once being considered as second- or even third-class institutions to having attained an equal and sometimes even dominant role in the American political scene.

The problem of differentiating between what is and what is not permissible concerning the interference of the judicial branch in political issues can be best illustrated by the Shelby County v. Holder ruling. On one hand, we have the desirable reaction on the part of the Supreme Court to modify regulations in the most important anti-discrimination 
election law in history, since it is the judges' role to interpret the law, including the supreme law, i.e. the Constitution, especially when a citizen questions the constitutionality of a specific act. On the other hand though, we can observe the potential effects of resolving the dispute, which may lead to far-reaching changes in the American political scene. One might venture to say that such changes have already taken place as a result of reforming election procedures in several countries. At the same time, the Shelby precedent fully illustrates the essence of American constitutionalism, which is its politicization. Analysis of the reactions of Democratic and Republican party politicians points to a deep polarization of opinions on the 2013 ruling. The criticism expressed by the liberals is dampened by the enthusiasm of the conservatives. The source of this division, however, is not the fact of bipartisanship itself in the American political system, but the influence of this bipartisanship on how the Supreme Court operates. If we analyse the judicial method of argumentation and the votes in the Shelby dispute, we can discern a repeated pattern of ideological voting in matters of a political nature. Conservative justices were the authors of the majority judgment, whereas the liberal minority signed dissenting opinions (570 U.S. 2, 2013). The same pattern can be found in the Court rulings on financing election campaigns, especially since 2005 , when a conservative bloc of justices, having a one-vote advantage over the others, essentially controlled the Court. The appointment of the new justice for the position held by late Antonin Scalia upheld the status quo, since Neil Gorsuch represents identical views as those of his predecessor (Laidler 2016).

\section{Conclusions}

The dominant role of the courts in determining the constitutionality of election laws and processes is one of the symptoms of the judicial activism in American politics which can be observed over the past few decades. More and more spheres traditionally reserved for other branches of government are being appropriated by the Supreme Court, which actively exercises its constitutional competencies. While inter- 
ferences aimed at protecting the rights and freedoms of individuals, as well as the powers allocated to particular institutions of authority, seems justified, the involvement of the judicial branch in the organization or the course of elections is much less obvious. The problem generally stems from the politicization of many spheres of public life in the United States, including election processes, whose effects will always be of a political nature. On the other hand, the excessive politicization and ideologization of the judicial branch strengthens the polarization of the political scene, generating counter-arguments in the discussions concerning the role and effectiveness of the judicial branch. Today, political courts make political decisions, as a result of which candidates for governmental offices take part in political campaigns in order to gain influence on political processes. This is particularly visible in the rulings on financing election campaigns, thus many scholars are right to claim that the Supreme Court dominates over Congress in the sphere of future reforms of financing federal election campaigns.

However, there have been some cases when the court's interference in election issues went too far, such as in 2000 when conservative judges decided that George W. Bush would become the President of the United States (Bush v. Gore, 531 U.S. 98). On one hand the Supreme Court ended the period of anxious anticipation for the final decision on who won the race to the White House, but on the other hand it got into the very centre of perhaps the most important political process, where there should not have been a place for the judicial branch. The reaction of American politicians and the public opinion was very typical, because - as in other analysed cases - it depended on political preferences and one's professed ideology. And thus we are caught in a vicious circle: a politicized Supreme Court makes political decisions which are subjected to political evaluation by the politicians, who will in turn influence the composition of the Court in the future. Judicial activism in American politics is a fact, and we may only argue about the scale of this phenomenon. 


\section{Bibliography}

Legislation / court rulings

Amendments to Federal Election Campaign Act 88 Stat. 1263 (1974).

Amendments to Federal Election Campaign Act 90 Stat. 475 (1976).

Amendments to Federal Election Campaign Act 93 Stat. 1339 (1980).

Amendments to Publicity Act 37 Stat. 25 (1911).

Ashwander v. Tennessee Valley Authority 297 U.S. 288 (1936).

Baker v. Carr 369 U.S. 186 (1962).

Bipartisan Campaign Reform (An Act to Amend the Federal Election Campaign Act of 1971 to Provide Bipartisan Campaign Reform) 116 Stat. 81 (2002).

Buckley v. Valeo 424 U.S. 1 (1976).

Bush v. Gore 531 U.S. 98 (2000).

California Medical Association v. F.E.C. 453 U.S. 182 (1981).

Citizens United v. F.E.C. 558 U.S. 310 (2010).

Colorado Republican Federal Campaign Committee v. F.E.C. 518 U.S. 604 (1996).

Davis v. Bandemer 478 U.S. 109 (1986).

Davis v. F.E.C. 554 U.S. 724 (2008).

Davis v. Mann 377 U.S. 656 (1964).

F.E.C. v. Colorado Republican Federal Campaign Committee 533 U.S. 431 (2001).

F.E.C. v. Massachusetts Citizens for Life 479 U.S. 238 (1986).

F.E.C. v. National Conservative Political Action Committee 470 U.S. 480 (1985).

F.E.C. v. Wisconsin Right to Life 551 U.S. 449 (2007).

Federal Corrupt Practices Act 43 Stat. 1070 (1925).

Federal Election Campaign Act (An Act to Promote Fair Practices in the Conduct of Election Campaigns for Federal Political Offices, and for Other Purposes) 86 Stat. 3 (1971).

Gray v. Sanders 372 U.S. 368 (1963).

Help America Vote Act 116 Stat. 1666 (2002).

The United States Constitution

Lucas v. Forty-Fourth General Assembly of Colorado 377 U.S. 713 (1964).

Maryland Committee for Fair Representation v. Taws 377 U.S. 656 (1964). 
McConnell v. F.E.C. 540 U.S. 93 (2003).

McCutcheon v. F.E.C. 572 U.S. 12-536 (2014).

Miller v. Johnson 515 U.S. 900 (1995).

National Voter Registration Act 107 Stat. 77 (1993).

Newberry v. United States 256 U.S. 232 (1921).

Pendleton Act (An Act to Regulate and Improve the Civil Service of the United States) 22 Stat. 43 (1883).

Publicity Act 36 Stat. 822 (1910).

Reynolds v. Sims 377 U.S. 633 (1964).

Roman v. Sincock 377 U.S. 695 (1964).

Shaw v. Reno 509 U.S. 630 (1993).

Shelby County v. Holder 570 U.S. 2 (2013).

Thornburg v. Gingles 478 U.S. 30 (1986).

Tillman Act (An Act to Prohibit Corporations from Making Money Contributions in Connection with Political Elections) 34 Stat. 864 (1907).

United States v. Nixon 418 U.S. 683 (1974).

Vieth v. Jubelirer 541 U.S. 267 (2004).

Voting Rights Act 79 Stat. 437 (1965).

Wesberry v. Sanders 376 U.S. 1 (1963).

WMCA v. Lomenzo 377 U.S. 633 (1964).

Literature

Ball, H. (200o). The Bakke Case. Race, Education and Affirmative Action. Lawrence: University Press of Kansas.

Banaszak, B., Bernaczyk., M. (2012). Aktywizm sędziowski we współczesnym państwie demokratycznym. Warszawa: Wydawnictwo Sejmowe.

Collier, C., Collier, J. L. (2007). Decision in Philadelphia: the Constitutional Convention of 1787. Philadelphia: Ballantine Books.

Darby, D. (2016). 'Uncovering the Voting Rights Act: the Racial Progress Argument in Shelby County', Kansas Journal of Law and Public Policy, vol. XXV, 329-346.

Greenberg, E.S., Page, B.I. (2005). America's Democratic Republic. New York: Pearson Longman. 
Hamilton, A., Madison, J., Jay, J. (1999). Federalist Papers. New York: Mentor Book.

Hasen, R. L. (2012). 'Judges as Political Regulators. Evidence and Opinions for Institutional Change', in: C.E. Guy-Uriel, H.K. Gerken, M.S. Kang (eds.). Race, Reform, Regulation of the Electoral Process. Recurring Puzzles in American Democracy, New York: Cambridge University Press.

Hall, K.L., Ely, Jr., J.W. (eds.) (2009). The Oxford Guide to the U.S. Supreme Court Decisions. New York: Oxford University Press.

James, S.C. (2006). 'Patronage Regimes and American Party Development from 'The Age of Jackson' to the Progressive Era', British Journal of Political Science, 36:1, 39-60.

Karlan, P.S. (2013). A Constitution for All Times. Boston: MIT Press.

Kozłowski, K. (2014). 'Instytucja gerrymanderingu w prawie amerykańskim', in P. Laidler, J. Szymanek (eds.). Idee, instytucje i praktyka ustrojowa Stanów Zjednoczonych Ameryki. Kraków: Wydawnictwo Uniwersytetu Jagiellońskiego, 275-294.

Kubas, S. (2013). 'Ingerencja amerykańskiego sądu konstytucyjnego w proces wyborczy. Uwagi na tle orzeczenie Citizens United v. Federal Election Commission (2010)', in A. Zięba (ed.). Konstytucjonalizm w państwach anglosaskich. Kraków: Wydawnictwo Uniwersytetu Jagiellońskiego, 431-440.

Laidler, P., Turek, M. (2016). Cena demokracji. Finansowanie federalnych kampanii wyborczych w Stanach Zjednoczonych Ameryki. Kraków: Księgarnia Akademicka.

Laidler, P. (2016). 'Prawno-polityczny spór wokół wyboru sędziego Sądu Najwyższego Antonina Scalii', Przegląd Sejmowy, 134: 3, 21-44.

Laidler, P. (2015) 'Republikanie i Demokraci wobec procesu judykalizacji amerykańskiej polityki: analiza z perspektywy problemu legalizacji małżeństw osób tej samej płci', Studia Politicae Universitatis Silesiensis, 15, 98-126.

Laidler, P. (2011). Sąd Najwyższy Stanów Zjednoczonych Ameryki. Od prawa do polityki. Kraków: Wydawnictwo Uniwersytetu Jagiellońskiego.

Mutch, R.E. (2014). Buying the Vote. A History of Campaign Finance Reform. New York: Oxford University Press.

Oświecimski, K. (2011). 'Finansowanie kampanii wyborczych w USA - rozwój regulacji, ich konsekwencje i aspekty polityczne', Horyzonty polityki, 2, 241-295. 
Peacock, A. (2005). 'Election Regulations', nn E. Meese III, D.F. Forte, M. Spalding (eds.). The Heritage Guide to the Constitution. Washington D.C.: The Heritage Foundation, 71-73).

Rosen, J. (2007). The Supreme Court: The Personalities and Rivalries that Defined America. Nowy Jork: Henry Holt and Company.

Sellers, J.S. (2015). 'Shelby County as a Sanction for States' Rights in Elections', Saint Louis University Public Law Review, vol. XXXIV, 367-384.

Shapiro, M., Sweet, A.S. (2002). On Law, Politics, and Judicialization, New York: Oxford University Press.

Skrzypiński, D. (2014). 'Odpowiedzialność sędziów w świetle zjawiska judykalizacji polityki', Wrocławskie Studia Politologiczne, 17, 53-64.

Sokól, W., (2013). 'Systemy wyborcze: mechanizmy, typologie i konsekwencje polityczne', in Z. Kiełmiński, J. Szymanek (eds.). Instytucje prawa konstytucyjnego w perspektywie politologicznej. Warszawa: Dom Wydawniczy Elipsa, 46-70.

Turek, M. (2013). 'Amerykański system finansowania wyborów i jego konsekwencje', in A. Małek, P. Napierała (eds.). Stany Zjednoczone wczoraj i dziś: wybrane zagadnienia społeczno-polityczne. Kraków: Księgarnia Akademicka, 167-195).

Tushnet, M. (1999). Taking Constitution Away from the Courts. Princeton: Princeton University Press.

Vandewalker, I., Bentele, K.G. (2015). 'Vulnerability in Numbers: Racial Composition of the Electorate, Voter Suppression, and the Voting Rights Act', Harvard Latino Law Review, 18, 100-150.

Vieira, N., Gross, L. (1998). Supreme Court Appointments: Judge Borks and the Politicization of Senate Confirmations. Carbondale: Southern Illinois University Press.

Vile, J. R. (2006). A Companion to the United States Constitution and its Amendments. Westport: Praeger.

Whittington, K. E. (2007). Political Foundations of Judicial Supremacy. The Presidency, the Supreme Court, and Constitutional Leadership in U.S. History. Princeton: Princeton University Press.

Wieciech, T. (2014). Anglosaska formuła politycznego konstytucjonalizmu. Kraków: Wydawnictwo Uniwersytetu Jagiellońskiego.

Wilson, M. (2015). 'Piercing the Umbrella: the Dangerous Paradox of Shelby County v. Holder', Seton Hall Legislative Journal, 39, 182-204. 
Paweł Laidler is a professor of political science, lawyer, and specialist in American studies. Author of several books and articles in both Polish and English on the contemporary U.S. political and legal system, with a focus on the role of judiciary, the clash of law and politics in U.S. governmental institutions, the current character of the separation of powers, as well as the challenges of U.S. surveillance policies. Vice-Dean for Educational Affairs at the Faculty of International and Political Studies at the Jagiellonian University in Krakow. In 2015 Visiting Professor at the JFK Institute for American Studies at Freie Universitaet in Berlin.

\section{Paweł Laidler}

Jagiellonian University

Institute of American Studies and Polish Diaspora

Rynek Glowny 34

31-010 Krakow, Poland

e-mail: pawel.laidler@uj.edu.pl 